JaNice B. StockigT

\title{
Transmission of sacred music between Bohemia and Dresden as seen in the collection of Jan Dismas Zelenka
}

This paper addresses the question of how the Bohemian violone player Jan Dismas Zelenka (16791745) acquired a substantial collection of sacred music for use in Dresden's first post-Reformation Catholic church, which was established by August II and dedicated in 1708. This royal chapel was housed in the renovated court theatre "Am Taschenberg", and it was open for public worship. The collection of sacred music accumulated by Zelenka hints at his ambitious nature because a library such as his would have been a prerequisite for a role of musical responsibility - clearly a position to which he aspired!

By 1734, when Zelenka was appointed "Kirchen Compositeur" to the Dresden court, he had acquired (either through composition or by collecting) almost fifty Mass settings (including Masses by Palestrina that he and Philipp Troyer copied in Vienna during 1717), ${ }^{1}$ together with Mass movements, sacred Arias and Motets, and a number of Offertoria. Zelenka had composed a great many works for the Office of Vespers, in addition to which he had collected about sixty psalm and Magnificat settings by other composers. He also held settings of Litanies and Marian antiphons, and he had written at least two Requiems and music for Holy Week. Twice by 1731 he had set the Ambrosian Hymn, and Il serpente di bronzo (ZWV 61), the first of three large-scale oratorios, had been composed. ${ }^{2}$

The greater part of Zelenka's music collection was written, collected, and revised between 1725 and the early 1730s during that era known as the Interregnum, a term used by Wolfgang Horn to designate those years between the death of Kapellmeister Johann David Heinichen (1683-1729) and February 1734 when Johann Adolf Hasse (1699-1783) arrived to take up his position as Kapellmeister. ${ }^{3}$ When the catalogue (Catalogo) of the music collection of Dresden's new Catholic court church (the Hofkirche) was finalised in March 1765 under the supervision of the Dresden court

1 Zelenka's copies of Mass settings by Palestrina are included in the third volume (Liber III) of his collection titled Collectaneorum Musicoru[m]. libri 4 de diversis Authoribus. D-Dl: Mus.1-B-98. On the contents of Liber III, see Zelenka-Dokumentation: Quellen und Materialien, eds. Wolfgang Horn and Thomas Kohlhase, Wiesbaden 1989, vol. 1, pp. 75-85.

2 Zelenka's compositional output was published by Wolfgang Reich in Zelenka-Dokumentation 1989 (see fn. above), chapter "Die Werke in der Reihenfolge des ZWV”, vol. 2, pp. 285-312.

3 Wolfgang Horn, Die Dresdner Hofkirchenmusik, 1720-1745: Studien zu ihren Voraussetzungen und ihrem Repertoire, Kassel 1987, pp. 88-89. 
composer Johann Georg Schürer, more than 200 of the 800 or more items listed there either were composed or collected and reworked by Zelenka. ${ }^{4}$ Indeed, it was his collection - together with the collections of Kapellmeister Johann David Heinichen (1683-1729), ${ }^{5}$ Giovanni Alberto Ristori (1692-1753), ${ }^{6}$ and sacred music composed by Kapellmeister Johann Adolph Hasse - that formed the greater part of the library of sacred music held by the Hofkirche as catalogued by Schürer.

The acquisition of Zelenka's musical estate for Dresden was due to the patronage of the daughter-in-law of August II, Queen and Electress Maria Josepha (1699-1757). ${ }^{7}$ It was she who took ultimate responsibility for the collection of church music until her death, a duty inherited by her daughter-in-law, Maria Antonia Walpurgis (1724-1780), the wife of Saxon Elector Friedrich Christian (1722-1763). This is known from the record of an account requiring payment dated $26 \mathrm{March}$ 1764 presented to the Dresden court's Directeur de Plaisirs, Friedrich August von König, namely:

"I have presented a cleanly written copy of the recently compiled two catalogues (2. Catalogis) of the [late] Elector's holdings of church music to Her Royal Highness the Churfürstin [Maria Antonia] because Her Highness has at her very own disposal all remaining music that until now had been in the possession of Her Majesty, the [late] most highly blessed Queen [Maria Josepha]. According to the account signed by concertmaster [Carl Matthias] Lehneis, these two catalogues cost 18 Thaler. Therefore [I] await your Royal Highness's highest order as to whether the Theatre Cassa will add this to its expenses."

The accompanying Resolution, dated 27 March, states the following: "3.) For the copies of two Catalogis of the electoral church music collection the necessary payment of 18 [Thaler] has been made." 9

4 Catalogo della Musica di Chiesa 1765. Compiled under the supervision of Johann Georg Schürer, 3 vols. Manuscript in D-B: Mus.ms.theor. Kat. 186.

5 The loss of much of the music from Heinichen's musical estate is discussed by Gerhard Poppe, "Über historisches Gedächtnis in der Kirchenmusik: Zur Bearbeitung zweier Messen von Johann David Heinichen durch Joseph Schuster", in: Händel-Jahrbuch 47 (2001), pp. 137-156.

6 Great losses from the musical estate of Ristori also occurred. His output was catalogued by Curt Rudolph Mengelberg, in Giovanni Alberto Ristori: Ein Beitrag zur Geschichte italienischer Kunstherrschaft in Deutschland im 18. Jahrhundert, Leipzig 1916.

7 Moritz Fürstenau, Zur Geschichte der Musik und des Theaters am Hofe zu Dresden. Vol. 2, Zur Geschichte der Musik und des Theaters am Hofe der Kurfürsten von Sachsen und Könige von Polen Friedrich August I. (August II.) und Friedrich August II. (August III.), Dresden 1861-62. Reprint Leipzig 1971, p. 181.

8 "Ich habe von denen neuerl.[ich] verfertigten 2. Catalogis des Churfl. Kirchen Music-Vorraths eine sauber geschriebene Copëy Ihrer Königl.[ichen] Hoheit der Churfürstin übergeben, weil Höchstdieselben alle übrige Music, welche sonst bey Ihro Maiest. [Majestät] der Höchstseeligen Königin gestanden, in höchst dero Selbsteigenen Beschluß haben. Diese 2. Catalogi kosten laut der von dem Concert-meister Lehneis attestirten Rechnung 18. r. [Thaler] wannenhero Ew. [Eure] Königl.[iche] Hoheit höchsten Befehl erwarte, ob die Theater Cassa diese Last bezahlen, und mit in Ausgabe verschreiben solle?” Sächsisches Staatsarchiv - Hauptstaatsarchiv Dresden (D-Dla hereafter), 10026 Geheimes Kabinett (Geh. Kab. hereafter), Loc. 910/1, Acta. Das Churfürstl: Orchestre und deßen Unterhaltung ingleichen. Das große Opern-Haus und andere zum Departement des Directeur des Plaisirs gehörige. Angelegenheiten betr. Anno [1711, 1717], 1764 [...] 68, f. 82b-83a [right column]. (NB: this archive replaces $r-v$ with a-b). The original account signed by concertmaster Carl Matthias Lehneis is not kept with this request.

9 “3.) für die von den Zwey Catalogis des Churfürstl. Kirchen=Music=Vorraths gefertigte Abschriften die 
It is fortunate that Zelenka's personal inventory (Inventarium) has survived because it provides a key to understanding certain sources among his holdings of Mass and Vespers compositions. It is proposed that this inventory also reveals the networks he developed with various religious institutions and colleagues in Bohemia. Zelenka's Inventarium, combined with catalogues from Bohemia, provides the major reference points for this study. The primary sources are:

- Jan Dismas Zelenka, Inventarium rerum Musicarum Ecclesiae servientium. (begun on 17 January 1726$) ; ;^{10}$

- Catalogo (Thematico) [sic] della Musica di Chiesa (catholica [sic] in Dresda) composta Da diversi Autori - secondo l'Alfabetto 1765. Compiled under the supervision of "Joannes Georgius Schürer", 3 vols.; ${ }^{11}$

- Catalogus Musicaliorum. Anno 1720, in Ordinem digestus ab codem à quo et Annô 1733 est renovatus. A non-thematic catalogue begun in 1720 by choirmaster [Regens chori] Florian Burian of the Cistercian monastery at Osek. Continued 1723; 1724; 1733 (and later); ${ }^{12}$

- Catalogus Musicalium pro Chorò Ossecénsi. (a thematic catalogue begun c.1753-1754 by Regens chori P. Nivard Sommer at the Cistercian monastery at Osek, and continued by several other scribes) $;^{13}$

- Inventariu[m] Rerum, et Instrume[ntorum] Musicalium Chori Slanens[is]: Schol: Piar: Innovatum sub R. P. Tobia Thoma à S. Elia Dom, Rectore. Anno Reparatae Salutis. 1713. Unfoliated. Into this inventory of the Piarist college of Slaný additional entries were made in 1745, 1751,1756 , and $1760 .^{14}$

Secondary sources consulted for this study include the published catalogue of the music collection of the Metropolitan Cathedral of Prague, ${ }^{15}$ and the catalogue of the large music collection once held by the Prague church St Francis Seraphicus of the Order of the Cross with Red Star (German:

erforderl.[iche] Zahlung von 18 Thalern geleistet worden.” D-Dla: 10026 Loc. 910/1, f. 82a [left column]. I am very grateful to Dr. Barbara Reul and Susanne Haring for their assistance with transliteration and translation of these passages.

10 D-Dl: Bibl.Arch.III.Hb,Vol.787.d, http://digital.slub-dresden.de/id425379515.

11 D-B: Mus.ms.theor. Kat. 186. The insertions are in the hand of the noted music collector, Georg Poelchau (17731836), who acquired this source from Dresden.

12 Národní museum, České muzeum hudby, hudebně-historické oddělení, Prague (CZ-Pnm): 65/52. Entries into this catalogue extend beyond 1733: there are several entries of works by "Hasse", one of which accompanies his name with the notes “Cap: Magst:” and “Dresd:”. (f. 27r). Although appointed earlier, Johann Adolf Hasse finally arrived in Dresden as Kapellmeister in February 1734. On this inventory of Osek see also Barbara A. Renton, The Musical Culture of Eighteenth-Century Bohemia, with Special Emphasis on the Music Inventories of Osek and the Knights of the Cross. Ph.D. diss., New York 1990, Ann Arbor 1995.

13 CZ-Pnm: 65/52.

14 Vlastivědné muzeum ve Slaném, Slaný, Central Bohemia.

15 Jiří Štefan, Ecclesia Metropolitana Pragensis catalogus collectionis operum artis musicae, 2 vols, Prague 1983 and 1985 (Catalogus artis musicae in Bohemia et Moravia cultae. Series IV: Artis musicae antiquioris catalogorum). This work owes much to an earlier catalogue published by Antonius Podlaha, Catalogus collectionis operum artis musicae quae in bibliotheca capituli metropolitani Pragensis asservantur, Prague 1926. 
Kreuzherren; Czech: Křižovnický). Although now missing, this catalogue is reproduced as the Appendix to the thesis of Jiří Fukač. ${ }^{16}$

As it would be expected, a selection of sacred works by Viennese composers is found in Zelenka's collection. Not only had he been sent to the Imperial capital to study with Kapellmeister Johann Joseph Fux (1660-1741), but Viennese-based composers - Antonio Caldara (1670-1736) for example - would have been known to Zelenka. Works of both Fux and Caldara also were well represented in Bohemian collections. Zelenka also held many sacred works by Italian composers and the most likely source of these was the great supply of Italian music that came to Bohemia in 1717. Already it has been pointed out that the secretary to Count Stefan Kinsky, Baltazar Knapp, had lived for more than eight years in Italy, mainly in Naples and Rome. During this time Knapp acquired an important collection of sacred music. Upon returning to Prague in 1717 Knapp sold a great portion of this collection to Karel Kryštof Gayer, the music director of Prague's Metropolitan Cathedral. ${ }^{17}$ The remainder was purchased by the cathedral itself whose Provost, Daniel Joseph Mayer, insisted that Gayer would ensure no losses to the collection, nor should the music make its way into other hands by being copied. ${ }^{18}$ Following Gayer's death in 1734, however, his widow sold her late husband's entire music collection to the Kreuzherren Order in Prague. This included part of the cathedral's share of the Knapp purchase (thereby creating a situation that now is difficult to unravel). Although the music catalogue of the Prague Kreuzherren collection (begun in or about 1737) is missing, both Jiří Fukač and Barbara Renton had access to this inventory for their respective doctoral theses prior to $1990 .{ }^{19}$ As noted above, the Appendix to the thesis of Jiri Fukač contains the only record of what is arguably the largest collection of sacred music in Bohemia of the eighteenth century. ${ }^{20}$

It is evident that Zelenka exchanged sacred works with the Cistercian monastery at nearby Osek in Northern Bohemia, and it is likely that he also had established contact with the Piarist college at Slaný in Central Bohemia. Music attributed to a composer named "Zelinka" once was held there. ${ }^{21}$ Works of Zelenka were held by the Piarist monastery at Podolínec, now in Northern

16 Jiří Fukač, Křižovnický hudební inventář: Příspěvek $k$ poznání křižovnické hudební kultury a jejího místa $v$ hudebním životě barokní Prahy, Ph.D. diss., Brno 1959, typescript copy.

17 Barbara Renton notes that Knapp originally offered his entire collection to Prague's Metropolitan Cathedral through Gayer, but the Cathedral could not afford Knapp's price of 300 florins. It did, however, purchase 200 florins worth from the collection and Gayer apparently acquired the rest. See Barbara A. Renton, The Musical Culture of Eighteenth-Century Bohemia 1990 (see fn. 12), p. 419 and fn. 46 (citing Anton Podlaha, Catalogus collectionis operum artis musicae, p. xvi-xvii). See also Jana Vojtéšková, "Die Zelenka-Überlieferung in Böhmen und in der Tschechoslowakei”, in: Zelenka-Studien I: Referate der Internationalen Fachkonferenz Jan Dismas Zelenka (1679-1745), Marburg, J.-G.-Herder-Institut, 16.-20. November 1991, eds. Thomas Kohlhase and Hubert Unverricht, Kassel, 1993, pp. 85-108 (Musik des Ostens. 14).

18 Marie Kostílková, “An Outline of the History of the St. Vitus' Music Choir”, Introduction to Jiří Štefan, Ecclesia Metropolitana Pragensis catalogus 1983-1985 (see fn. 15) vol. 1, pp. 79-101, at p. 93. The emphasis is added by this author.

19 Catalogus Musicaliorum. Anno 1720. See fn. 12, above.

20 Fukač, Křžzovnický 1959 (see fn. 16, above).

21 The following works attributed to "Zelinka" are entered into the catalogue of the Slaný Piarist college: In 1709 Ad arma sonate for Bass solo was added as the $53^{\text {rd }}$ listing under the heading "Conc: de Temp ae"; in 1751 the seventh listing entered under the title "Missae Breviores" is Missa ex Cà C.A.T.B. Violinis $2^{\text {bus }}$ et Tympanis necessariis. Auctore sigl. Zelinka. It also is possible that Zelenka gave himself a "nom de plume" to hide his identity: 
Slovakia, ${ }^{22}$ and by the Piarist monastery of the Bohemian town Kosmonosy (located about 50 $\mathrm{km}$ northeast of Prague), ${ }^{23}$ while the Cathedral of Breslau (Wrocław, Silesia) held a Credo (in D) attributed to Zelenka. ${ }^{24}$ For Zelenka, the Jesuits from Dresden's Catholic court church with their vast networks in Bohemia (almost all the Dresden-based Jesuits from the Province of Bohemia had been associated with Prague's Clementinum college at one time or another) must have represented another channel for exchanges of music. With the suppression of the Society of Jesus in the 1770s, however, great losses to their music collections throughout the Province of Bohemia occurred. ${ }^{25}$ When a new sacred composition reached Zelenka he would revise and adjust the work to serve the performance forces available to him, adding parts for a viola, ripieno oboes and bassoons. These additions enriched the sonority of Dresden's sacred music, enhancing the sound for which the sacred music of Dresden's Catholic court church had become renowned. ${ }^{26}$ Today, the Music Department of the Sächsische Landesbibliothek - Staats- und Universitätsbibliothek Dresden holds a source that might appear to be unremarkable. It is, however, one of extreme value because it illustrates exactly the process followed by Zelenka when he modified a composition to suit the musical taste of the court, the acoustic conditions of Dresden's first post-Reformation Catholic court church, and the musicians available to him.

From an unknown source Zelenka received four parts for a setting of the Marian antiphon Salve Regina. These are for canto solo, two violins, and organ (D-Dl: Mus.2371-E-1b). The canto

in 1713 the Piarist college at Slaný received a copy of a Missa Sanctae Caeciliae attributed to "Domino Joannes Kallasska”. If this were found to be Zelenka's earliest known Mass (ZWV 1) there would be good reason for him to assume another name: on 31 January 1712 Zelenka had dedicated his Missa Sanctae Caeciliae (ZWV 1) to August II. (The autograph dedication is kept in A-Wn: Sign 15773). The 58 ${ }^{\text {th }}$ listing (1713) under the heading "Conc: de Temp" ae" titled "Amo[r] Deum" is also attributed to "D’no Joannes Kallasska", while listings Nos 105 and 106 under "Miscellanea" (1713) of "Maria gustum sentis" for alto, two violins and organ, and "Omni die" for the same combination, also are attributed to Kallasska.

22 An incomplete set of parts (1770) for the Requiem (ZWV 48) commissioned by Maria Josepha c.1730-1732 for the anniversary of her father, Joseph I (now missing in Dresden) once held by the Piarist monastery at Podolínec (Kláštor Piaristov, Podolínec) now is kept in the Štatný okresný archív Bratislava-vidiek (SK-J: H-252), while ten parts for the doubtful attribution to Jan Dismas Zelenka (named "Signo Zielonka") of a Missa in D (ZWV 23) (dated "1768. Die 19 Mar. | Choro Podolinensi”) also are kept there (SK-J: H-102), also in Národní knihovna České republiky, Prague (CZ-Pu): Hlahol archive, Sign. 1847. Perhaps the letters “Po." in Zelenka’s Inventarium entered beside a group of three anonymous works for Vespers (p. 38, $N^{\text {os }} 41,42$, and 43) also refer to the Piarist monastery at Podolínec.

23 An item listed as "Usni milé dítě. C.A. [?], V[iolin] S[olo?] accessit anno 1712 Zelenka" is listed under the heading "Natalitia”. See Zdenek Culka, "Inventáře hudebních nástrojů a hudebnin piaristické koleje v Kosmonosích", in: Přispěvky k dějinám české hudby II, Prague 1972, pp. 5-43, at p. 24 ( $\mathrm{N}^{\circ}$ 537).

24 "Symbolum Fidei, seu Credo, Sanctus etc: ex D\# Zelencka”. See Rudolf Walter, "Das Musikalienverzeichnis der Breslauer Kathedrale aus dem Jahr 1761”, in: Fontes Artis Musicae 35 (1988), p. 263.

25 An early copy of the complete version of Zelenka's Missa Nativitatis Domini (ZWV 8) is held in the Národní knihovna České republiky, Prague as a set of fifteen parts whose title page reads: "Missa Integra [...] Authore Signr. Zelenka | Chori Soc tis Iesu | Micro-Pragae. 1736”. (CZ-Pu: 59 R 2033). Ten parts for the already-mentioned Missa in D of doubtful authenticity (ZWV 23) from the "Chor S ${ }^{\text {cti }}$ Nicolai SJ M[icro] Prage" (see fn. 22, above) also are held in Prague (CZ-Pu: 59 R 2032). These examples are discussed by Václav Kapsa in "Die Musik in der St. Nikolauskirche auf der Prager Kleinseite in der ersten Hälfte des 18. Jahrhunderts”, in: Musicologica Brunensia 49 (2014), pp. 189-209, at p. 204.

26 Moritz Fürstenau cited reports published by J. C. Crell (“Iccander”, 1723) and C. C. Schramm (1744) that extolled the beauty of the music heard in the Catholic court church. Zur Geschichte der Musik 1971 (see fn. 7), p. 39. 
part bears the author's name: "Sigl. P. J. Maÿer." The watermark with the digitised facsimile reveals the paper came from Bensen, a Bohemian town close to the border with Saxony. ${ }^{27}$ Elsewhere I have suggested that the composer might be a Jesuit priest named "Pater Wenceslaus Maÿer S. J." (also "R[ev.].P[ater]. Mayer"; “P. Mayer”; “P. Majier” and "Mayer S. J.”), ${ }^{28}$ whose name accompanies works listed in the non-thematic music catalogue of the Piarist college at Slaný and the Piarist monastery at Kosmonosy. ${ }^{29}$ The catalogue of the Cistercian monastery at Osek also lists a number of smallscale items attributed to a Jesuit named "Majer S. J." or "Maÿer S. J.", while Dablacz knew of a seminarian named Johann Mayer who, between 1719 and 1720, was associated with the church of St Benedict in Prague's Old Town. ${ }^{30}$ Therefore, the identity of the author named Mayer of the Salve Regina remains uncertain at present.

From the four parts received in Dresden a score was prepared (D-Dl: Mus.2371-E-1) by a copyist who began working for Zelenka in the early 1730s, whose hand is classified by Wolfgang Horn as "Zelenka-Schreiber 1" ("ZS 1"). ${ }^{31}$ Zelenka's revisions are seen with the addition of instructions for the upper instrumental parts showing where the ripieno oboes either were to enter ("T[utti]") or to cease ("VV", meaning "violins only") with corresponding instructions given for the continuo section ("R[ipieno]" and "Or[gano]"). Occasional dynamics, alterations to text underlay, and additional notation of the bass line also appear in Zelenka's hand, and his cover title to this source states it to be an anonymous setting ("N: N:"). Another hand, however, has added "Maÿer" to the title page where Zelenka gave the scoring as "à Soprano Solo | Violin 2 | Oboe 2 | Viola | e | Basso Continuo." The number "14" noted in Zelenka's hand in the upper right corner of the cover corresponds with the fourteenth listing of an anonymous Salve Regina entered into the Inventarium. ${ }^{32}$ The addition of ripieno players brings a new aural dimension to this rather simple setting, which already was regarded at its source as being a good work. ${ }^{33}$ From the revised score, ten parts were prepared by the copyist "ZS 1" for soprano, two first violins (at the head of a violin part "S. P." is written - an indication that Dresden concertmaster "Signor Pisendel" had led at least one performance of the revised setting); two second violins; one viola part (notated in bass clef, this part follows the basso continuo part in the hand of "ZS 1", but Zelenka finalised the part when additional composition was required); violone; two oboes; organ - but lacking parts for bassoon(s). Not only did this copyist fully realise Zelenka's instructions by ensuring uniformity of articulation and

27 Bensen (Czech: Benešov nad Ploučnicí) is a town in the Ústí nad Labem region of the Czech Republic. Information on the source of this watermark was kindly provided by Claudia Lubkoll. Digitized watermark: http:// digital.slub-dresden.de/id426603648/13.

28 See Janice B. Stockigt, "Bach's Missa BWV 232 in the context of Catholic Mass settings in Dresden, 1729-1733", in: Exploring Bach's B-minor Mass, Cambridge 2013, eds. Yo Tomita, Robin Leaver and Jan Smaczny, pp. 39-53, especially p. 51.

29 In the Inventář hudebních nástrojů a hudebnin piaristické koleje v Kosmonosích, Zdenek Culka lists items attributed to "Majer", "P. Majier", "Mayer S. J.”, "P. Mayer”, and "R. P. Mayer”.

30 Gottfried Johann Dlabacz [Bohumír Jan Dlabacž], Allgemeines historisches Künstler-Lexikon für Böhmen und zum Theil auch für Mähren und Schlesien, 3 vols., Prague 1815, pp. 289-290.

31 Wolfgang Horn, "Die wichtigsten Schreiber im Umkreis Jan Dismas Zelenkas. Überlegungen zur Methode ihrer Bestimmung und Entwurf einer Gruppierung der Quellen”, in: Thomas Kohlhase and Hubert Unverricht, Zelenka-Studien I 1993 (see fn. 17), pp. 141-210, at pp. 155-157.

32 Inventarium, p. 49: “[1]4. Salve Canto Solo. Violin 2 | oboe 2 viole e Orga: N. N:”.

33 "bonu[m]" is written in the upper right corner of the organ part received in Dresden. 
dynamics, but in one instance the second oboe part was altered so that it avoided playing notes outside the range of the instrument - an attribute of a good copyist, according to Jean-Jacques Rousseau writing thirty years later. ${ }^{34}$

Did Zelenka purchase this Salve Regina setting, or was it part of an exchange? Who was he dealing with? And how would a value be placed on a work such as this? Would it be calculated according to length, or by the number of actual vocal and instrumental parts? We know that in 1729 Zelenka offered evidence for a court case claiming how he would charge for the composition of a set of arias, stating that "if commissioned to write twelve theatre arias in five parts without unisons, I would not do it for less than 12 ducats." 35

The great volume of sacred music circulating in Bohemia during the eighteenth century is indeed remarkable. Items from Vienna and Italian centres predominated, with significant contributions from local Bohemian composers. The great collections of the Cistercians at Osek, of Prague's Kreuzherren Order, and the Metropolitan Cathedral of Prague, demonstrate that while Zelenka held works listed in catalogues of each institution, each of those institutions held works by Zelenka!

\section{The letters "Oss" and “O” (Osek)}

A major centre for Zelenka's exchanges of music was the Cistercian monastery at Osek in the Teplice District of Bohemia, whose Regens chori (choirmaster), Florian Burian, kept a non-thematic inventory from 1720 until c.1733. ${ }^{36}$ Zelenka's Inventarium lists a number of Mass and Vespers compositions accompanied either by the underlined letters "Oss", or by the letter "O" (sometimes “O."). He seems to have noted these letters with Inventarium entries to remind himself that the listed composition had been received from Osek, and they are seen with entries only up to about 1730 . These letters accompany listings only of Mass settings and works for Vespers. They never are seen in listings of genres such as litanies and motets. The letters "Oss" and / or "O" are never written against Zelenka's own compositions (see illustration).

Table 1 demonstrates that altogether five (perhaps six) of the Mass settings entered into the Inventarium are accompanied by "Oss". Two are by the Imperial Vice-Kapellmeister Antonio Caldara (Inventarium listings $\mathrm{N}^{\circ} 19$ [deleted] and $\mathrm{N}^{\circ}$ 23). The score of Missa S: Petri Apostolo$r u[\mathrm{~m}]$ by the Bohemian composer Antonín Reichenauer ( $\left.\mathrm{N}^{\circ} 24\right)$ is in the hand of "ZS 0", a copy-

34 “Les Parties de Hautbois qu'on tire sur les Parties de Violon pour un grand d'Orchestre, ne doivent pas être exactement copiées comme elles sont dans l'original: mais, outre l'étendue que cet Instrument a de moins que le Violon; outre les Doux qu'il ne peut faire de même; outre l'agilité qui lui manque ou qui lui va mal dans certaines vitesses, la force du Hautbois doit être ménagée pour marquer mieux les Notes principales, \& donner plus d'accent à la Musique. Si j'avois à juger du goût d'un Symphoniste sans l'entendre, je lui donnerois à tirer sur la Partie de Violon, la Partie de Hautbois; tout Copiste doit savoir le faire." Entry titled "Copiste" in Jean-Jacques Rousseau, Dictionnaire de musique, Paris 1768, pp. 130-131.

35 "Se mi fosse stato ordinato di far dodeci arie da teatro con cinque parti senza unisoni io non le farei meno di dodeci ungari." Given by Daniel E. Freeman, “An 18th-Century Singer's Commission of 'Baggage’ Arias”, in: Early Music 20 (1992), pp. 427-433, at p. 430, and p. 433, fn. 12.

36 Catalogus Musicaliorum. Anno 1720. See fn. 12, above. 


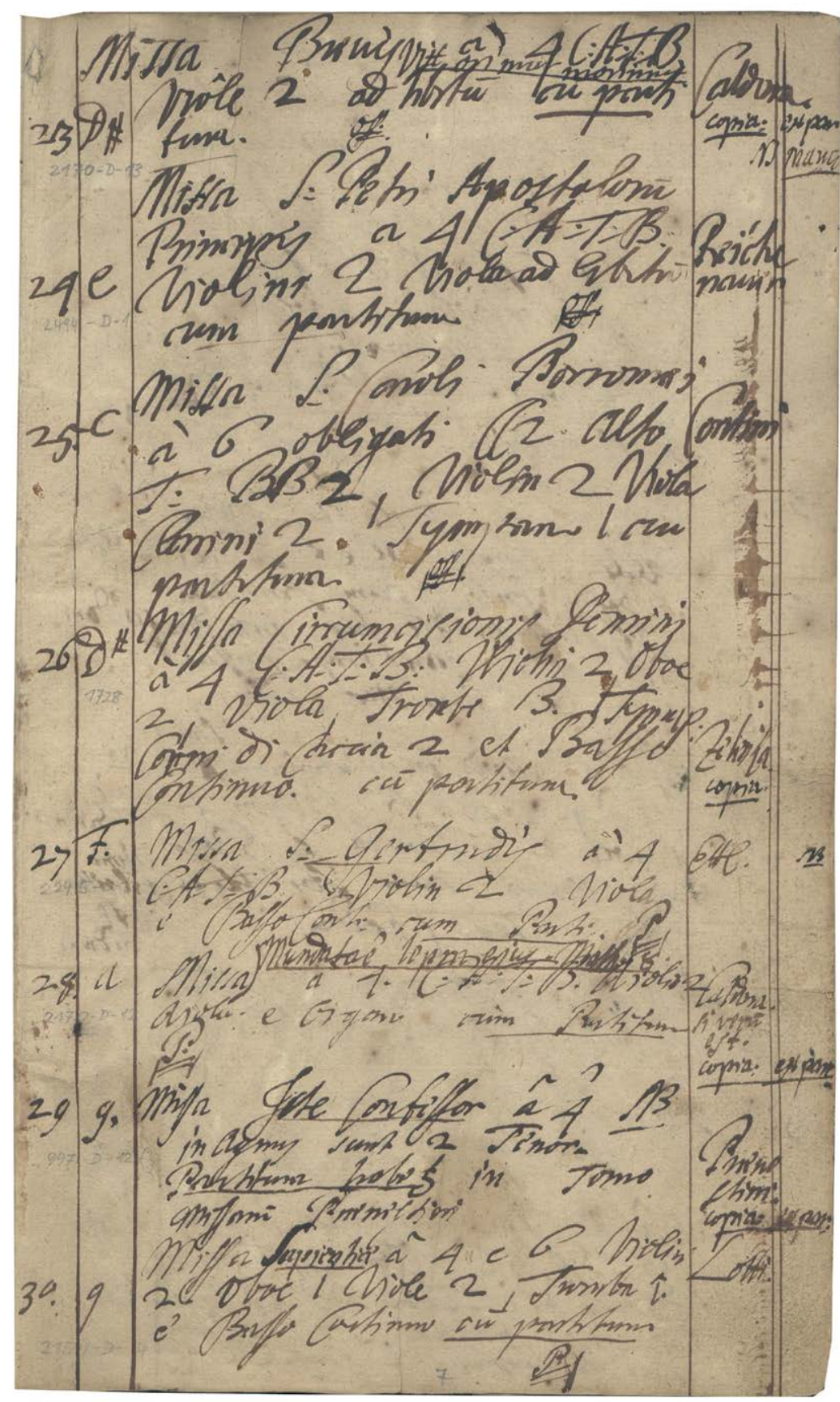

Illustration: Page 7 (recent pagination) from Zelenka's Inventarium rerum Musicarum Ecclesia servientium (D-Dl: Bibl.Arch.III.Hb,Vol.787.d), in which his method of notating the source of an acquisition is illustrated either with "Oss" (Osek: conclusion of $\left.\mathrm{N}^{\mathrm{os}} 23,24,25\right)$ or "P" (conclusion of $\mathrm{N}^{\mathrm{os}} 27,28,30$ ). All entries are situated within the third column of the page next to the title entries

ist who worked for Zelenka from $c .1725$ until the early $1730 \mathrm{~s} .{ }^{37}$ One, possibly two entries are of Mass settings by the Habsburg court composer and theorbist, Francesco Conti (listings $\mathrm{N}^{\circ} 25$ and $\mathrm{N}^{\circ}$ 32), named "Contini" by Zelenka in the Inventarium. These two musicians must have become acquainted between 1716 and 1719 during the time that Zelenka lived in Vienna, and probably again in 1723 when Conti travelled to Prague with the Viennese court ensemble to per-

37 Horn, Schreiber 1993 (see fn. 31), pp. 154-155. 
form the opera Costanza e Fortezza composed by the Imperial Kapellmeister Johann Joseph Fux. ${ }^{38}$ On page 9 of the Inventarium Zelenka also listed a Mass by Antonio Bioni in D accompanied by the letter "O" (originally No 39, now obliterated). The entry reads "Missa delicta juventutis meae ne memineris, Dne. a 4 C:ATB: Bioni. O: NB". This Mass, together with a Mass setting by Johann Friedrich Fasch, was obliterated when Zelenka pasted over the two entries with a slip on which he wrote details of Masses by "Eberlen" (Johann Ernst Eberlin; № 39) and "Breinik" (Father Johann Michael Breunich SJ; No 40). Perhaps the Mass entered by Zelenka on page 11 as "55: Missa à 4 Bioni $\mathrm{d \# "} \mathrm{is} \mathrm{"Missa} \mathrm{delicta} \mathrm{juventutis} \mathrm{meae} \mathrm{ne} \mathrm{memineris,} \mathrm{Dne".}$

In return, seven solemn Mass settings in $\mathrm{D}$ with trumpets and timpani by Zelenka are among those listed in the non-thematic catalogue of Florian Burian under the title "Continuatur Missae ab A: 1723 procurata" (Continuation of Masses procured from the year 1723), ff. $2 \mathrm{v}-3 \mathrm{r}$. These must represent the seven solemn settings with trumpets composed by Zelenka between 1723 and late 1729: Missa Sancti Spiritus, ZWV 4; Missa Paschalis, ZWV 7; Missa Nativitatis Domini, ZWV 8; Missa Corporis Domin[ic]i, ZWV 9; Missa Charitatis, ZWV 10; Missa Circumcisionis D. N.J. C, ZWV 11; Missa Divi Xaverii, ZWV 12. In Florian Burian's catalogue Zelenka's Mass settings were titled thus: "Missa à Credo [...] ex d. pomposseo[?] et longiss'o"; "Missa S: Eustachiis pomposa ex d"; "Missa S: Rosariis Brevis. Solem. ex d 1 $1^{\text {ae }}$ Classis"; "Missa S. Joannis Nepom: ex d. 2: Classis"; "Missa S: Floriani ex d. I ${ }^{\text {mae }}$ Classis NB"; "Missa DEI Agno Sacra ex d. cu[m] Credo I ${ }^{\text {mae }}$ Classis"; "Missa ex d S: Antoniis: Ie Classis." ${ }^{\text {ae }}$ Moreover, a copy of Zelenka's now-missing Requiem (ZWV 49) also was held at Osek at one time. ${ }^{40}$

Numerous compositions for the Office of Vespers seen in Zelenka's Inventarium also are accompanied by the letter "Oss" or "O", as Table 2 demonstrates. The final listings with the letter "O", Nos 48 to 51, date from c.1730, with items by Antonio Vivaldi, Santo Lapis, and Antonio Negri, father of the contralto Maria Catterina Negri who was based in Prague in the mid-1720s to sing for the opera seasons of Count Franz Anton von Sporck. The cover to the copy of Negri's Beatus vir, now held in Prague's Národní Muzeum, bears the statement "Antonio Negri - Beatus vir | Osecky Kláster." ${ }^{\prime 11}$ Listing № 48 (Vivaldi’s Magnificat with Zelenka’s Inventarium note “O”) definitely refers to Osek. This item, now missing in Dresden, implies that Zelenka had received

38 The "Kays. Compositeur et Theorbista Franz Conti" is listed with the musicians who travelled to Prague for the performance of Fux’s opera. Conti was accommodated at “375 Karmelitergasse Bey der golden Kron [. . .].” See Paul Nettl, Das Prager Quartierbuch des Personals der Krönungsoper 1723. Mitteilungen der Kommission für Musikforschung 8, Vienna 1957, p. 6.

39 The entry on f. 3v as "Missa ex d S: Antoniis" is certainly Missa Divi Xaverii (without "Credo") of 1729 (ZWV 12). A listing in Osek's thematic Catalogus Musicalium pro Chorò Ossecénsi of c.1753/4 (f. 9r, № 32, see fn. 13, above) is certainly of ZWV 12 (without title) for "Kyrie" and "Gloria" (the Kyrie incipit for violin 2, notated an octave higher than the autograph score: D-Dl: Mus.2358-D-26), accompanied by the Mass sections and scoring of the Dresden example: "Kyrie Gloria, Sanctus, et Agnus à C:A:T:B: Concert: et Ripieno, Violinis, Violis-Flautravers, Hobois 2. Trombist, tympanis, Violonzello, Fagotto, Violone Ripieno cu[m] Organo”. Zelenka's Missa Dei Patris (ZWV 19, f. 14r), Missa Nativitatis (ZWV 8, f. 19r), and Missa Purificationis (ZWV 16, f. 20v) also are found among the listings of this later thematic catalogue.

40 Ten parts dated "1730" for the Introit and Sequence from Zelenka's Requiem in F (ZWV 49) are now kept in Prague’s Národní Muzeum, CZ-Pnm: XXXIII A 75. They once were held by Florian Burian at Osek. The cover bears the inscription "Floriano Burian Oss: Prof: | A. 1730". The stamp is "Osecky kláster". One violin part has the inscription “M. P." (Monsieur Pisendel). 
Vivaldi's work from Osek and had processed it in the manner already described for Mayer's Salve Regina. Five voices (SSATB) were reduced by Zelenka to four (SATB) - the most usual choral arrangement for vocal ensembles of Dresden's Catholic court church during the 1720s. It is suggested that Zelenka returned Florian Burian's parts to Osek in a Dresden folder (an Umschlag) to which Burian added his own notations of scoring (including parts for two sopranos). The source of Vivaldi's Magnificat in G minor once held by Florian Burian (RV 610b) is one of three different manuscripts kept in Prague. Michael Talbot writes that the version held by Florian Burian was composed for the Pietà in Venice around $1715 .^{42}$

Proof also is available in Florian Burian's inventory that certain Vespers works came to Dresden from Osek. Items that Zelenka came to hold and revise in $c .1727$ were procured for Osek beginning three years earlier according to the date given at the top of an extract that appears on fol. 36r of Burian's inventory (see Table 6). Note that the thirteenth listing with these works acquired by Osek in or after 1724 was a Laudate pueri setting for solo canto attributed to Zelenka ("Laudate pueri ex d solo Canto Zelenka"), an unidentified setting. Florian Burian's catalogue also lists a number of small-scale sacred items attributed to a composer named "Zelenka" (or similar). They are: "Te adoro te suspira bis. Cum viola d'amor Zelencka" (f. 10r); "Ad jubar Serenum. Selenka" (f. 10v); "Haec dies, quam fecit Domin[us] di festivite D’ni ex g Zelenka" (f. 22v); "Motteto per il Natale. T. solo il Concert: Zelencka", and "Aria per il Natale de N: J: S: à Contralto Zelenka" (f. 26v); ${ }^{43}$ "E[euer] Vatter der [?] Barmhertzigkeit à C et B de Quadragis: Zelenka" (vernacular, after Luke 6; 36); "Tantum ergo ab Alto Solo Zelenka” (followed by “jam alibi stat" [now in another place] noted in darker ink); ${ }^{44}$ and "Cantabile de SS Sacramento Ave Dei Zelenka" (f. 27r); "Aria de Solemnite pompos: di B: S[olo]: ad celebrandus Zelencka” (listed twice: f. 27v; f. 34r).

\section{The Letters "P" or "P"}

Another sign seen with listings in Zelenka's Inventarium is the letter " $\mathrm{P}$ " whose meaning is uncertain at present. See Table 3. The letter might indicate an institution, ${ }^{45}$ a person, ${ }^{46}$ or a place. ${ }^{47}$ The letter "P" cannot signify parts (Parti) because Zelenka's entries imply that these already exist (otherwise why would he write "cum Partitura" with most of the Mass listings?). Moreover, the letter " $\mathrm{P}$ " is not seen in the Inventarium with any item composed by Zelenka himself: it is found only among entries of Masses and compositions for Vespers. As already noted with the "Oss" and "O"

42 Michael Talbot, The Vivaldi Compendium, Suffolk c.2011, pp. 112-113. This example is discussed by the present writer in "Musica senza nome dell'Autore: anonymous works in the Catalogo of the music collection of the Dresden Hofkirche, 1765”, in: Studi vivaldiani 7 (2007), p. 10.

43 It is likely that the "Motteto per il Natale" and "Aria per il Natale de N: J: S" are Zelenka's own reworkings as motets of two arias from his Melodramma de S. Wenceslao of 1723 (ZWV 175): Pro quo criminis (ZWV 172), c.1725. D-Dl: Mus.2358-E-34; O Magnum Mysterium (ZWV 171), c.1728. D-Dl: Mus.2358-E-501; -E-501a.

44 Perhaps this entry is the hymn "Tantum ergo" listed by Wolfgang Reich as an unidentified work: ZWV 244. See

"Die Werke in der Reihenfolge des ZWV", in: Zelenka-Dokumentation 1989 (see fn. 1), vol. 2, p. 312.

45 The Premonstratensian monastery at Strahov in Prague, for example?

46 Jan Josef Ignáz Prentner? Or Franz Poppe, for example?

47 Prague, for example? 
listings, Zelenka ceased using this letter in the early 1730s, before he composed Missa Sancti Josephi ZWV 14 (c.1732), as seen in Table 3. With two exceptions only - No 27, Missa S: Gertrudis by Mathias Ettl (Oettl) and No 39, Missa Adjutorium nostrum by Domenico Sarri (Sarro), a concordance for each of these works is found in the collections of Prague's Metropolitan Cathedral and / or the Kreuzherren collection, as shown in Table 5 (see below).

It is Zelenka's psalm collection, however, that demonstrates his very great dependence upon a person, a place, or an institution identified with the letter "P” (see Table 4). Of Zelenka's fifty-eight entries of Vespers compositions (many of which are multiple listings), twenty-seven are accompanied by the letter "P". Interestingly, the listing of three psalms by Johann Caspar Ferdinand Fischer $\left(\mathrm{N}^{\circ} 4\right)$ is not accompanied by this letter, ${ }^{48}$ possibly because these works were copied from Fischer's 1701 publication: Vesperae seu psalmi vespertini pro toto anno, op. 3 (Augsburg, 1701), as suggested by Wolfgang Horn. ${ }^{49}$ Thus, in this case, Zelenka was not dependent upon an exchange or purchase of music. Nor is the letter " $\mathrm{P}$ " seen with listing $\mathrm{N}^{\circ} 12$, the obliterated setting of Zelenka's own Laetatus sum (ZWV 88) composed c.1726 (which suggests the date of acquisition of and / or reworking of the works that are entered above: 1726 or earlier). Table 4 shows that after the missing anonymous works, $\mathrm{N}^{\circ} 29$ to $\mathrm{N}^{\circ} 34$, the letter "P" is seen no more with the Vespers listings. Note that both the letters "O" and "P" accompany this group of anonymous settings for Sunday Vespers. Perhaps Zelenka received these works twice, once from Osek, and once either from Prague's Metropolitan Cathedral or from the Kreuzherren Order. ${ }^{50}$

Incipits of these anonymous psalms and Magnificat for a "Vesperae de Confessore" are today found in the collection of Prague's Metropolitan Cathedral where they were attributed to "Sig[nor] Dorante". ${ }^{51}$ This same cycle, to which a Marian Vespers cycle has been added, also was held by the Kreuzherren Order in Prague. ${ }^{52}$ Vaclav Kapsa identified these Vespers works as being composed by Josef Ignáz Brentner or Prentner (1689-1742), and has found that examples from this collection were held in Osek and in Slaný - albeit in a very disorganised state. Apart from being attributed to "Dorante" (Francesco Durante) in the collection of Prague's Metropolitan Cathedral, these settings are attributed variously to "Schmidt", Václav Gunther Jacob, and "Brixi". ${ }^{53}$ Kapsa regards the Dresden listings of Brentner's psalms as being known only through catalogues such as Zelenka's Inventarium and the Catalogo (1765). There, a Vespers de Confessore cycle is listed among anony-

48 D-Dl: Mus.1865-D-1. Copied by “ZS O”.

49 See Horn, Hofkirchenmusik 1987 (see fn. 3), pp. 134-135.

50 Table 1 shows that Zelenka's listing of a Credo by Aldrovandini also is accompanied by both letters.

51 This collection is partly in the hand of Jan František Novák (1706-1771), provenance Josef Antonín Sehling (1710-1756). See Jiř́ Štefan, Ecclesia Metropolitana Pragensis catalogus 1983-1985 (see fn. 15), ([329] Sign. 315), partim Novák, prov. Sehling. CATB, violin 1, violin 2, two organ parts; Archiv Pražského hradu (CZ-Pak): 315, RISM ID no. 550269679.

52 Rytířský řád křižovníků s červenou hvězdou, hudební sbírka, Prague (CZ-Pkřiž): XXXV B 231. Attributed to Josef Jan Ignác Brentner. From a group of psalms, titled "Salmi | del |Confessore | à 4 voci | 2 VViolinis | con | Organo. | Authore | Brentner”. Parts for C, C Rip, A, T, B, violin 1, violin 2, organ, trumpet in D. Post 1730. RISM ID no. 550248620 .

53 Václav Kapsa, "On the Way from Prague to Wrocław: Sacred Music by Early 18th-Century Prague Composers in Silesia”, in: Musical Culture of Silesia before 1742: New Contexts, New Perspectives, eds. Pawel Gancarczyk, Lenka Hlávková-Mráčková and Remigiusz Pośpiech, Frankfurt a. M. 2013, pp. 267-287, especially Table 3b (Eastern European Studies in Musicology. 1). 
mous items in the section "Musica senza nome dell'Autore", and two of three works for a Marian Vespers are listed as anonymous works under "d'Ignoti." ${ }^{4} 4$ For almost every entry of a Mass or Vespers composition listed with the letter "P" a concordance is found in the catalogues of Prague's Metropolitan Cathedral and / or the Kreuzherren collection, as demonstrated in Table 5 regarding the Mass settings.

\section{Misattributions}

The question arises of incorrect attribution in Zelenka's collection. In his Inventarium, and also in the Catalogo 1765, false claims of authorship have become obvious. ${ }^{55}$ For example, the first Vespers compositions Zelenka listed under the heading "Psalmi Varioru[m] Authorum", $\mathrm{N}^{\circ} 1$ to $\mathrm{N}^{\circ} 3$ and $\mathrm{N}^{\circ} 10$, were originally entered as anonymous works ("Ignoti") and replaced by "Novari", Jan František Novák (1706-1771). ${ }^{56}$ (Perhaps his identity was hidden because of his association with Prague's Cathedral. Later, in 1737 Novák was appointed music director there following the death of Kapellmeister Johann Anton Gerbich [Görbig] - a position he held until 1758). Zelenka's attribution of Beatus vir $\left(\mathrm{N}^{\circ} 7\right)$ to Carlo Cozzi is ascribed to Antonio Negri in the collection of Prague's Cathedral. Moreover, the attribution in Zelenka's Inventarium to "Fabris" (Annibale Pio Fabri, 1697-1750) of a Vespers de Confessore cycle is made only in Dresden, which seems to be among the earliest of the numerous sources of these works appearing throughout the eighteenth century. Today, these same settings are found in at least twelve European locations, including Austrian, Hungarian, German, and Polish archives, as well as the Prague collections of the Metropolitan Cathedral, the Národní Muzeum, and the Kreuzherren. These settings are variously attributed to Giovanni Schmidt, Ferdinand Schmidt, Vincenz Schmidt, as well as to Mathias Öttl, and "Haas". ${ }^{77}$ On the other hand, an important misattribution in the music library of Prague's Metropolitan Cathedral is a copy of a set of parts for Zelenka's Kyrie and Gloria from his Missa Dei Patris (ZWV 19, with trumpets!) attributed to "Ristori". ${ }^{8}$ A copy of the earliest version of the Gloria from Zelenka's Missa Judica me (ZWV 2) is held today as an unattributed setting in the col-

54 Confitebor, [Schrank] III/ [Fach] 31/ [Lage] 4; Beatus vir III/31/12; Laudate pueri III/31/20; Laudate Dominum, III/32/2; Magnificat, III/32/13 (Kapsa considers this Magnificat setting might have been composed by Durante). Further settings of psalms for a Marian Vespers by Brentner are listed in the Catalogo (1765) under d'Ignoti: Laudate pueri, I/1/35/2; Magnificat, I/1/35/3.

55 Gerhard Poppe, "Kontinuität des Repertoires? Einige Bemerkungen zur Kirchenmusik am Dresdner Hof zwischen 1697 und 1717”, in: Miscellaneorum de Musica Concentus. Karl Heller zum 65. Geburtstag am 10. Dezember 2000, eds. Walpurga Alexander, Joachim Stange-Elbe and Andreas Waczkat, Rostock 2000, p. 78, established that the setting of Laetatus sum, which Zelenka attributed to "Foschi", was composed by Carlo Luigi Pietro Pietragrua (Carlo Luigi Pietro Grua; Pietro Grua).

56 The Catalogo (1765) gives the name "Noack" for three works once in Zelenka's possession, now attributed to Jan František Novák: O sacrum convivium (D-Dl: Mus.3847-D-1); Alma Redemptoris Mater (D-Dl: Mus.3847-E-2); two Ave Regina settings (D-Dl: Mus.3847-E-1).

57 The advice of Michael Driscoll on these various sources is acknowledged with gratitude.

58 CZ-Pak: 1101. Incipits of a Kyrie et Gloria setting which correspond with these movements of Missa Dei Patris (ZWV 19) are attributed to Giovanni Alberto Ristori, "partim S[ehlin]g". Parts are for C, A, T, B, violin 1 (2x), violin 2, viola, trumpet 1 in C, trumpet 2 in C, violone, organ. Listed by Štefan, Ecclesia Metropolitana Pragensis catalogus 1983-1985 (see fn. 15) ([1152] Sign. 1101), partim Sehling. 
lection of Anton Moritz Taubner, a musician from Prague's Loreto convent where this work once was associated with the sodality "Jesus Maria Joseph". 59

The transmission of sacred music between Dresden and Bohemia, and vice-versa, remains a topic for ongoing study - one that always will be "work in progress". To determine the networks established by a composer such as Zelenka and the history of transmission of sacred music between him and contacts he established in Bohemia requires detailed analysis of individual works and sources of the kind already undertaken by Jana Vojtéšková and Vaclav Kapsa. ${ }^{60}$ This will be a task for those with an interest in the movement northwards and the subsequent spreading further afield of a rich and varied repertoire of sacred music from centres where the music of Italian composers flourished. In the 1720s the transmission of music to Dresden brought new concepts and novel ideas to Zelenka which then became incorporated into his highly personal and unique voice that once was heard in the sacred music that accompanied worship in Dresden's Catholic court church.

59 National Archives, Prague (CZ-Pa): Loreto box ŘK 259-262. I am very grateful to Robert Hugo for drawing my attention to this source.

60 See Jana Vojtéšková's examination of the Dresden and Prague sources of Antonio Lotti’s Missa Sapientiae in "Bach, Zelenka a hrabě Hartig", in: Hudební věda 31 (1994), pp. 145-148, and Vaclav Kapsa’s published studies, as shown above (see fn. 25 and fn. 53). 
Table 1: Mass settings in Zelenka’s Inventarium with the margin note Oss or O. (Osek)

\begin{tabular}{|c|c|c|c|c|c|c|c|}
\hline $\mathrm{N}^{\circ}$ & $\begin{array}{c}\text { Date } \\
\text { revised }\end{array}$ & Key & Title & Composer & Letter $[\mathrm{s}]$ & Copyist & D-Dl: Mus. \\
\hline 16. & \multicolumn{6}{|c|}{ Zelenka: Missa Charitatis (ZWV 10: c.1727) } & 2358-D-23 \\
\hline 17. & \multicolumn{6}{|c|}{ Zelenka: Missa S. Spiritus (ZWV 4: 1723 / c.1727/8) } & $\begin{array}{l}2358-\mathrm{D}-18,1, \\
2358-\mathrm{D}-18,2\end{array}$ \\
\hline 19. & & $\{C]$ & Missa S: Caroli Boromei & Antonio Caldara & $\underline{\underline{\text { Oss: }}}$ & - & Missing $^{61}$ \\
\hline 21. & \multicolumn{6}{|c|}{ Zelenka: Missa S: Caeciliae (ZWV 1: c.1710; revised c.1727/8) } & $2358-\mathrm{D}-8$ \\
\hline 22. & \multicolumn{6}{|c|}{ Missa Corporis Domini[ci] (ZWV 9: c.1727/8) } & $2358-\mathrm{D}-25$ \\
\hline 23. & c. 1728 & $\mathrm{D} \#$ & $\begin{array}{c}\text { Missa Brevis 'Vix orimur } \\
\text { morimur' }\end{array}$ & Ant $^{\text {io }}$ Caldara & $\begin{array}{l}\underline{\underline{\text { Oss }}}, \text { 'NB: } \\
\text { manca' }\end{array}$ & $\begin{array}{l}\text { ZS O and } \\
\text { Zelenka }\end{array}$ & 2170-D-13 \\
\hline 24. & c. 1728 & $\mathrm{e}$ & $\begin{array}{c}\text { Missa S: Petri Aposto- } \\
\text { loru }[\mathrm{m}]\end{array}$ & $\begin{array}{l}\text { Joh. Anton[ín] } \\
\text { Reichenauer }\end{array}$ & $\underline{\text { Oss }}$ & ZS O & 2494-D-1 \\
\hline 25. & c. 1728 & $\mathrm{C}$ & Missa S: Caroli Borromei & Francesco Conti & $\underline{\underline{O s s}}$ & - & Missing $?^{62}$ \\
\hline 26. & \multicolumn{6}{|c|}{ Zelenka: Missa Circumcisionis Domini (ZWV 11: 1728) } & $2358-\mathrm{D}-24$ \\
\hline 32. & c.1729 & $\mathrm{gb}$ & Missa Mirabilium & Francesco Conti & $\begin{array}{c}\text { Oss } \\
\text { [only partly } \\
\text { legible] }\end{array}$ & $\mathrm{ZS} \mathrm{O}$ [var] & $2190-\mathrm{D}-2$ \\
\hline 35. & \multicolumn{6}{|c|}{ Zelenka: Missa Divi Xaverii (ZWV 12: 1729) } & $2358-\mathrm{D}-26$ \\
\hline 36. & & \multicolumn{5}{|c|}{ Zelenka: Missa Gratias agimus tibi (ZWV 13: 1730) } & 2358-D-21 \\
\hline 39. & & $\bigoplus$ & $\begin{array}{c}\text { Missa Deticta jutrentutis } \\
\text { meate }\end{array}$ & Antonio Biont & $\begin{array}{c}\Theta . \\
\mathrm{ANB}^{\prime}\end{array}$ & ZS 2 & 2498-D-1 \\
\hline 42. & \multicolumn{6}{|c|}{ Zelenka: Missa S. Josephi (ZWV 14: c.1732) } & $2358-\mathrm{D}-43$ \\
\hline
\end{tabular}

61 Zelenka obliterated this listing by pasting a strip over the entry with a listing of Missa Suscipe Deprecationem by "Reiter", probably Georg von Reutter (1656-1738). D-Dl: Mus.2979-D-8.

62 Perhaps this is D-Dl: Mus.2637-D-1 from the estate of Dresden Kapellmeister Joseph Schuster. See RISM ID no. 212009091.

63 Zelenka obliterated this listing by pasting a strip over the entries listing a Missa in F (Missa sine nomine composed by Johann Friedrich Fasch) and Missa Delicta juventutis meae (Antonio Bioni) with Masses by Johann Ernst Erberlin and Fr Johann Michael Breunich. The Missa by Bioni is probably the same work listed later in the Inventarium (p. 11) as number 55: “Missa à 4 Bioni. D\#”. Zelenka made very few revisions to this Dresden example. 
Table 2: Vespers works in Zelenka’s Inventarium with margin note “Oss:” or “O.” (Osek)

\begin{tabular}{|c|c|c|c|c|c|c|c|}
\hline $\mathrm{N}^{\mathrm{o}}$ & $\begin{array}{l}\text { Date } \\
\text { revised }\end{array}$ & Key & Title & Composer & $\begin{array}{l}\text { Let- } \\
\text { ter[s] }\end{array}$ & Copyist & D-Dl: Mus. \\
\hline 12. & $\begin{array}{c}\text { Composed } \\
\text { c. } 1726\end{array}$ & \multicolumn{5}{|c|}{$\begin{array}{l}\text { Eaetatus à } 4 \text { C.A.T.B. VV 2. Viola, Oboe ad libi[tum]. NB Spectat ad Psal= } \\
\text { mus totius anni ejusdem }\end{array}$} & 2356-D-61,3 \\
\hline 15. & c. $1726 / 7+$ & $\mathrm{Gb}$ & Laudate pueri & $\begin{array}{l}\text { [Domenico] } \\
\text { Gabrieli }\end{array}$ & Oss: & $\mathrm{ZS} \mathrm{O}$ & $2120-\mathrm{E}-1$ \\
\hline 17. & & $\mathrm{D} \#$ & Beatus à 4 & Borri & Oss: & $\mathrm{ZSO}$ & 2059-D-1 \\
\hline 18. & & $\mathrm{C}$ & Magnificat à 4 & Aldrovandini & Oss: & $\mathrm{ZS} \mathrm{O}$ & 2204-D-3 \\
\hline 29. & & $\mathrm{D}$ & Dixit à 4 & Anonymi & P. : O. & - & Missing \\
\hline 30. & & $\mathrm{~Gb}$ & Confitebor à 4 & [Prenter] & P. : O. & - & Missing \\
\hline 31. & & B & Beatus à 4 & [Prenter] & P. : O. & - & Missing \\
\hline 32. & & $\mathrm{D} \#$ & Laudate pueri à 4 & [Prenter] & P. : O. & - & Missing \\
\hline 33. & & $\mathrm{~F}$ & Laudate Dominum à 4 & [Prenter] & P. : O. & - & Missing \\
\hline 34. & & G & Magnificat à 4 & [Anonymi] & P. : O. & - & Missing \\
\hline 48. & & {$[\mathrm{~g}]$} & Magnificat à 4 & Ant. Vivaldi & O. & - & Missing \\
\hline 49. & & $\mathrm{~Gb}$ & Dixit à 4 & Santo Lapis & O. & - & Missing \\
\hline 50. & c. $1730+$ & $\mathrm{F}$ & Laudate pueri à 3 & Ant $^{\text {io }}$ Negri & O. & ZS 1 & 2883-D-1 \\
\hline 51. & & $\mathrm{~F}$ & Beatus à 2 C:A: & Ant ${ }^{\text {io }}$ Negri & O. & ZS 1 & 2883-D-2 \\
\hline
\end{tabular}


Table 3: Mass settings in Zelenka's Inventarium with the margin note "P"or "P".

\begin{tabular}{|c|c|c|c|c|c|c|c|}
\hline $\mathrm{N}^{\circ}$ & $\begin{array}{c}\text { Date } \\
\text { revised }\end{array}$ & Key & Title & Composer & Letter $[\mathrm{s}]$ & Copyist & D-Dl: Mus. \\
\hline & c. 1727 & $\mathrm{~F}$ & Credo & Aldrovandini & $\begin{array}{l}\text { Oss: } \\
\underline{\underline{P}}\end{array}$ & ZS 1 & 2204-D-2 \\
\hline 10. & c. 1727 & $\mathrm{D}$ & Missa Providentiae & Caldara & $\underline{\underline{P}}$ & ZS O & $2170-\mathrm{D}-7$ \\
\hline 11. & c. 1727 & B & Missa Modestiae & Durante & $\underline{\underline{\mathrm{P}}}$ & $\mathrm{ZS} \mathrm{O}$ & 2397-D-10 \\
\hline 12. & $c .1727$ & $\mathrm{D \#}$ & Missa Temperantiae & $\begin{array}{l}\text { Manzini } \\
{[\text { Mancini }]}\end{array}$ & $\underline{\underline{P}}$ & $\mathrm{ZS} \mathrm{O}$ & 2203-D-2 \\
\hline 13. & c. 1727 & $\mathrm{D \#}$ & Missa Magnanimitatis & [A] Scarlatti & $\underline{\underline{\mathrm{P}}}$ & - & Missing \\
\hline 14. & c. 1727 & $\mathrm{D}$ & Missa Fiduciae & Fux & $\underline{\underline{P}}$ & Zelenka & 2130-D-1 \\
\hline 15. & c. 1727 & $\mathrm{G} \#$ & Missa vita hominis brevis est & Reinhardt & $\underline{\underline{\mathrm{P}}}$ & $\mathrm{ZS} \mathrm{O}$ & 2793-D-2 \\
\hline 16. & \multicolumn{6}{|c|}{ Zelenka: Missa Charitatis (ZWV 10: c.1727) } & 2358-D-23 \\
\hline 17. & \multicolumn{6}{|c|}{ Zelenka: Missa S. Spiritus (ZWV 4: 1723 / c.1727 / c.1728) } & $\begin{array}{l}2358-\mathrm{D}-18,1 \\
2358-\mathrm{D}-18,2\end{array}$ \\
\hline 21 & \multicolumn{6}{|c|}{ Zelenka: Missa S. Caeciliae (ZWV 1: 1712 /1720 / c.1727) } & $\begin{array}{c}2358-\mathrm{D}-7 \mathrm{a} \\
2358-\mathrm{D}-8\end{array}$ \\
\hline 22. & \multicolumn{6}{|c|}{ Zelenka: Missa Corporis Dominici (ZWV 9: c.1727) } & 2358-D-25 \\
\hline 26. & \multicolumn{6}{|c|}{ Zelenka: Missa Circumcisionis Domini (ZWV 11: 1728) } & 2358-D-24 \\
\hline 27. & c. 1729 & $\mathrm{~F}$ & Missa S: Gertrudis & Ettl [Oettl] & $\underline{\underline{P}}$ & ZS O & $2245-\mathrm{D}-1$ \\
\hline 28. & c. 1729 & A & $\begin{array}{c}\text { Missa Mundata est lepra } \\
\text { ejus }\end{array}$ & Caldara & $\underline{\underline{P}}$ & $\mathrm{ZS} \mathrm{O}$ & $2170-\mathrm{D}-12$ \\
\hline 30. & c. 1729 & G & Missa Sapientiae & Lotti & $\underline{\underline{P}}$ & $\mathrm{ZS} \mathrm{O}$ & 2159-D-4 \\
\hline 31. & $c .1729$ & $\mathrm{C}$ & $\begin{array}{l}\text { Missa Gloriae } \\
\text { (S. Spiritus) }\end{array}$ & Ettl & $\underline{\mathrm{P}}$ & ZS 2 & $2245-\mathrm{D}-2$ \\
\hline 35. & \multicolumn{6}{|c|}{ Zelenka: Missa S. Xaverii (ZWV 12: 1729) } & $2358-\mathrm{D}-26$ \\
\hline 36. & \multicolumn{6}{|c|}{ Zelenka: Missa Gratias agimus tibi (ZWV 13: 1730) } & $2358-\mathrm{D}-21$ \\
\hline 37. & $c .1730$ & {$[\mathrm{~A}]$} & Missa quid mihi et tibi & Caldara & $\underline{\underline{P}}$ & - & Score missing \\
\hline [39.] & c. 1730 & {$[\mathrm{D}]$} & $\begin{array}{c}\text { Missa Adjutorium nostrum } \\
\ldots\end{array}$ & Sarri [Sarro] & P. & ZS 2 & 2356-D-1 \\
\hline$[42]$. & \multicolumn{6}{|c|}{ Zelenka: Missa S. Josephi (ZWV 14: c.1732) } & $2358-\mathrm{D}-43$ \\
\hline
\end{tabular}


Table 4: Vespers works in Zelenka's Inventarium with margin note "P" or "P".

\begin{tabular}{|c|c|c|c|c|c|c|c|}
\hline $\mathrm{N}^{\circ}$ & $\begin{array}{l}\text { Date } \\
\text { revised }\end{array}$ & Key & Title & Composer & Letters & Copyist & D-Dl: Mus. \\
\hline 1. & c. 1726 & $\mathrm{C}$ & Dixit à 4 & $\begin{array}{l}\text { Novari fgnoti } \\
\text { [Novák] }\end{array}$ & $\underline{\underline{P}}$ & $\mathrm{ZSO}$ & Missing? \\
\hline 2. & & $a: g \#$ & Confitebor et Beatus vir & "ejusdem" & $\underline{\underline{P}}$ & $\mathrm{ZSO}$ & 3613-D-1 \\
\hline 3. & & $e: f$ & Laudate pueri, Laudate $D^{m n}$ & "ejusdem" & $\underline{\underline{\underline{P}}}$ & $\mathrm{ZSO}$ & $3613-\mathrm{D}-2$ \\
\hline 5. & & $\mathrm{~b}$ & Dixit Dominus & Tomaso Ingegnieri & $\underline{\underline{P}}$ & $\mathrm{ZS} \mathrm{O}$ & $1131-\mathrm{E}-4$ \\
\hline 6. & & $\begin{array}{c}\mathrm{cb} \\
\text { "Long:" }\end{array}$ & Laudate pueri & Caldara & $\underline{\underline{P}}$ & $\mathrm{ZSO}$ & $\begin{array}{l}\text { 2170-E-3; } \\
2170-E-3 a\end{array}$ \\
\hline 7. & & $\mathrm{a}$ & Beatus vir & Cozzi (attributed) & $\underline{\underline{\mathrm{P}}}$ & $\mathrm{ZSO}$ & 1487-E-1 \\
\hline 8. & & $\begin{array}{c}\mathrm{b} \\
\text { "brevius" }\end{array}$ & Dixit Dominus & Pitoni & $\underline{\underline{\mathrm{P}}}$ & $\mathrm{ZSO}$ & $2117-\mathrm{D}-3$ \\
\hline 9. & & $\begin{array}{c}\mathrm{b} \\
\text { "brevius" }\end{array}$ & Magnificat & Pitoni & $\underline{\underline{\mathrm{P}}}$ & $\mathrm{ZS} \mathrm{O}$ & 2117-E-1 \\
\hline 10. & & $\mathrm{C}$ & Magnificat & $\begin{array}{l}\text { Novari Ignoti } \\
\text { [Novàk] }\end{array}$ & $\underline{\underline{P}}$ & $\begin{array}{l}\text { Zelenka; } \\
\text { ZS O text }\end{array}$ & 3613-E-1 \\
\hline 11. & & $\mathrm{D \#}$ & $\begin{array}{l}\text { Laetatus sum: Nisi Domi- } \\
\text { nus }\end{array}$ & Ciaja & $\underline{\underline{P}}$ & & Missing \\
\hline 12. & $c .1726$ & $\mathrm{D \#}$ & \multicolumn{4}{|c|}{$\begin{array}{c}\text { Eaetatus à } 4 \text { C.A.T.B. VV 2. Viola, Oboe ad libi[tum]. NB Spectat ad Psatmus } \\
\text { totius anni ejusdem. Z (ZWV 88) }\end{array}$} & $2358-16,3$ \\
\hline 12. & $1726-8$ & D: & Laetatus & Foschi (attributed) & $\underline{\underline{\underline{P}}}$ & $\mathrm{ZS} \mathrm{O}$ & 1900-E-1 \\
\hline 13. & & $\mathrm{~Gb}$ & Beatus vir & Poppe & $\underline{\underline{\mathrm{P}}}$ & $\mathrm{ZSO}$ & $3610-\mathrm{D}-3$ \\
\hline 14. & & b. & Domine ad adjuvandum & Pitoni & $\underline{\underline{\mathrm{P}}}$ & & Missing \\
\hline 16 & & g\# & Beatus à 6 & Caldara & $\underline{\underline{\mathrm{P}}}$ & $\mathrm{ZS} \mathrm{O}[\mathrm{var}]$ & $\begin{array}{l}2170-\mathrm{E}-2 ; \\
2170-\mathrm{E}-2 \mathrm{a}\end{array}$ \\
\hline 19. & & $\mathrm{~b}: \mathrm{f}$ & Dixit; Confitebor à 4 & Šimon Brixi & $\underline{\underline{\mathrm{P}}}$ & & Missing \\
\hline 20. & & $c: g \#$ & Beatus; Laudate pueri & “ejusdem" & $\underline{\underline{\underline{\mathrm{P}}}}$ & & Missing \\
\hline 21. & & $\mathrm{D} \#: \mathrm{b}$ & Laudate Dom: Magnificat & "ejusdem" & $\underline{\underline{\mathrm{P}}}$ & & Missing \\
\hline 22. & & $\mathrm{D} \#$ : D\# & $\begin{array}{c}\text { Domine [ad adjuvandum]; } \\
\text { Dixit }\end{array}$ & Poppe & $\underline{\underline{P}}$ & & Missing \\
\hline 23. & & $\mathrm{D}: \mathrm{gb}$ & $\begin{array}{l}\text { Confitebor à C e B; } \\
\text { Beatus à } 4 \text { C.A.T.B. }\end{array}$ & "ejusdem" & $\underline{\underline{P}}$ & $\mathrm{ZS} \mathrm{O}$ & $3610-\mathrm{D}-2$ \\
\hline 24. & & $\mathrm{G}: \mathrm{D \#}$ & $\begin{array}{l}\text { Laudate pueri à } 2 \text { A.T. } \\
\text { Laudate Dom [inum] à } 4\end{array}$ & "ejusdem" & {$[\underline{\underline{\mathrm{P}}}]$} & $\mathrm{ZSO}$ & $3610-\mathrm{D}-4$ \\
\hline 25. & $\begin{array}{l}\text { Post } \\
1728\end{array}$ & $\mathrm{D \#}$ & Magnificat à 4 & "ejusdem" & {$[\underline{\underline{P}}]$} & $\begin{array}{l}\text { ZS O and } \\
\text { Zelenka }\end{array}$ & $3610-\mathrm{E}-1$ \\
\hline 27. & & $\mathrm{A \#}$ & Nisi Dominus à 2 A. T: & [Anonymi] & $\underline{\underline{\underline{P}}}$ & & Missing \\
\hline 28. & & $\mathrm{C}$ & Beatus à 4 & Del P: Urio & $\mathrm{P}$. & $\mathrm{ZS} \mathrm{O}$ & 2141-D-1 \\
\hline 29. & & $\mathrm{D}$ & Dixit à 4 & $\begin{array}{c}\text { Anonym } \\
\text { [Durante?] }\end{array}$ & P.: O. & & Missing \\
\hline 30. & & $\mathrm{~Gb}$ & Confitebor à 4 & $\begin{array}{c}\text { "ejusdem" } \\
\text { [Dorante/Prentner] }\end{array}$ & P. : O. & & Missing \\
\hline 31. & & B & Beatus à 4 & $\begin{array}{c}\text { "ejusdem" } \\
\text { [Dorante/Prentner] }\end{array}$ & P. : O. & & Missing \\
\hline 32. & & $\mathrm{~d} \#$ & Laudate pueri à 4 & $\begin{array}{c}\text { "ejusdem" } \\
\text { [Dorante/Prentner] }\end{array}$ & P.: O. & & Missing \\
\hline 33. & & $\mathrm{~F}$ & Laudate Dom[inum] & $\begin{array}{c}\text { "ejusdem" } \\
\text { [Dorante/Prentner] }\end{array}$ & P.: O. & & Missing \\
\hline 34. & & g & Magnificat & $\begin{array}{c}\text { "ejusdem" } \\
\text { [Anon./Prentner?] }\end{array}$ & P. : O. & & Missing \\
\hline
\end{tabular}


Table 5: Bohemian Sources of Mass settings acquired for Dresden by Jan Dismas Zelenka

\begin{tabular}{|c|c|c|c|}
\hline Composer & Title & D-Dl: Mus. & Bohemian sources \\
\hline Caldara & Missa Providentiae & $2170-\mathrm{D}-7$ & Kreuzherren collection: CZ-Pkřiž: XXXVI A 105 \\
\hline Durante & Missa Modestiae & 2397-D-10 & $\begin{array}{l}\text { Metropolitan Cathedral, Prague: Štefan, ([331] Sign. 319a). } \\
\text { An Italian copy? }\end{array}$ \\
\hline Mancini & Missa Temperantiae & 2203-D-2 & $\begin{array}{l}\text { - Metropolitan Cathedral, Prague. CZ-Pak: } 867 . \\
\text { Štefan, ([912] Sign. 867). Parts in Gayer's hand } \\
\text { - Kreuzherren (score): CZ-Pkřiž: XXXV D } 39 \\
\text { - Kreuzherren (parts): CZ-Pkřiž: XXXV D } 182 \\
\text { - Osek. Listed in both catalogues of 1720-33 } \\
\text { and c.1754-1810 }\end{array}$ \\
\hline A. Scarlatti: & Missa Magnanimitatis & Missing & $\begin{array}{c}\text { - Metropolitan Cathedral, Prague: CZ-Pak:1147, } \\
\text { prov. Sehling. } \\
\text { Two masses by “Scharlatti” are listed in the Kreuzherren } \\
\text { catalogue, and "Kyrie et Gloria ex a" in Osek's } \\
\text { non-thematic catalogue }\end{array}$ \\
\hline Fux & Missa Fiduciae & 2130-D-1 & CZ-Pkřiž: XXXVI A 76. Prov. Gayer \\
\hline Reinhardt & $\begin{array}{l}\text { Missa vita hominis } \\
\text { brevis est }\end{array}$ & 2793-D-2 & $\begin{array}{l}\text { - CZ-Pkřiž: XXXVI A } 26 \text { Set of parts "Sumptibus } \\
\text { Gayer": Also attributed here to "Caspari” } \\
\text { - CZ-Pak: 1075. Štefan, ([1125] Sign. 1075) }\end{array}$ \\
\hline Oettl & $\begin{array}{l}\text { Missa Gloriae (Missa } \\
\quad \text { Sancti Spiritus) }\end{array}$ & $2245-\mathrm{D}-2$ & $\begin{array}{c}\text { - CZ-Pkřiž: XXXV E } 66 \text { “Ex partibus Ch Gayer” } \\
\text { • CZ-Pkřiž: XXXVI }\end{array}$ \\
\hline Caldara & $\begin{array}{l}\text { Missa Mundata est } \\
\text { lepra ejus }\end{array}$ & $2170-\mathrm{D}-12$ & CZ-MEa: Sign. 38 \\
\hline Lotti & Missa Sapientiae & 2159-D-4 & $\begin{array}{l}\text { • CZ-Pkř̌ž: XXXVI A } 114 \\
\text { - Metropolitan Cathedral, Prague. CZ-Pak: } 854 . \\
\text { Gloria. Štefan, ([899] Sign. 855), prov. H. Hartig } \\
\text { - Metropolitan Cathedral, Prague. CZ-Pak: } 855 . \\
\text { Gloria à 5. Štefan, ([900] Sign. 855), prov. H. Hartig }\end{array}$ \\
\hline Caldara & Missa quid mihi et tibi & 2170-D-14 & $\begin{array}{l}\text { - "Missa S. Michaelis Archangeli”. CZ-Pkřiž: XXXV C } 124 \\
\text { - Metropolitan Cathedral, Prague: "Ex liberalitate Illmi DD } \\
\text { Episcopi Comitis D. Sporck donati et de perditi Credo } \\
\text { assumpta è post Obitum D. Görbig Cap [ . . .]" CZ-Pak: } 198 . \\
\text { Štefan, ([212] Sign. 198), prov. Novák. }{ }^{64}\end{array}$ \\
\hline
\end{tabular}

64 A set of ten parts held in the collection of the Metropolitan Cathedral, Prague. The materials for the "Credo" [s] had been donated to the Cathedral by Bishop Count Sporck, Prague Canon and titular Bishop of Adraa Johann Rudolph Sporck (1696-1759), nephew of Franz Anton Sporck. These were recovered after the death in 1727 of Kapellmeister Antonín Görbig. 
Table 6: Florian Burian's non-thematic catalogue 1720-1733+ (CZ-Pnm: 65/52)

"Ab anno 1724 procurata" (f. 36r)

\begin{tabular}{|c|c|c|c|c|}
\hline$\left[\mathrm{N}^{\circ}\right]$ & Title & Key & Composer $^{65}$ & Zelenka's Inventarium entry \\
\hline [5.] & $\begin{array}{c}\text { Psalmus Beatus vir a vocibus di- } \\
\text { versus }\end{array}$ & ex d & Borri & $\mathrm{N}^{\mathrm{o}} 17$ \\
\hline [7.] & Magnificat & ex C & Reinharth & No $26 ?$ \\
\hline [10.] & Psalmi Duo Dixit et Magnificat & & Anonymus & $\begin{array}{c}\text { Dixit } \mathrm{N}^{\circ} 29 ? \\
\text { Magnificat } \mathrm{N}^{\circ} 34 ?\end{array}$ \\
\hline$[11]$. & Cantion Magnificat & ex C & Altrovandini & $\mathrm{N}^{\mathrm{o}} 18$ \\
\hline [12.] & Vesperae integrae et brevis & - & Schmid & $\begin{array}{l}\text { Possibly these are the listings at- } \\
\text { tributed to Annibale Pio Fabri by } \\
\text { Zelenka. Inventarium } \\
\text { p. } 38, \mathrm{~N}^{\circ} 35-40\end{array}$ \\
\hline [13.] & Laudate pueri Solo Canto & ex d & Zelenka & An unknown work ${ }^{66}$ \\
\hline$[16]$. & Magnificat & ex g & Vivaldi & $\mathrm{N}^{\mathrm{o}} 48$ \\
\hline [17.] & Dixit Solemniter & ex d & Santo Lapis & No 49 \\
\hline
\end{tabular}

65 The original spellings of composers' names have been retained.

66 It is possible that this is an early working of the setting of $c .1729$ for solo tenor (later revised for solo soprano) 
